\title{
Performance Evaluation of Composite Steel-Concrete Shear Walls
}

\author{
Dr.D.K. Kulkarni and P.P. Phadnis
}

\begin{abstract}
The present work describes the theoretical study on steel-concrete shear wall with steel encased profiles. Shear walls are used in buildings to resist the lateral load induced during earthquakes. Shear walls generally have rectangular cross section with the high concentration of longitudinal reinforcement at the extremities of elements. The use of conventional reinforced concrete shear wall in multistoried buildings is sometimes limited because of the large amount of reinforcement localized at the end of the element. A good alternative in avoiding this disadvantage is to use composite steel concrete structural shear walls with steel encased profiles. Composite shear walls offer the advantages like flexural stiffening, strengthening of compression elements, improved deformability, increased floor area, fire protection, easy repairs and economy.
\end{abstract}

The study consists of numerical analysis on 1:3 scale steel-concrete composite elements. Composite steel-concrete shear walls are modeled as equivalent frame element and analyzed using SAP2000 pushover capability. Comparative study related to the behavior of composite steel-concrete shear wall with encased steel sections and conventional reinforced concrete shear wall. Presence of encased steel sections significantly increases base shear and slightly increases ductility.

Keywords--- Pushover Analysis, Composite Steel-Concrete Shear Wall, Material Non-Linearity, Ductility, Equivalent Frame Element

\section{INTRODUCTION}

$\mathrm{C}$ COMPOSITE steel-concrete shear walls are reinforced concrete shear walls with additional structural steel, usually located at the extremities of the cross section of the wall. The use of conventional reinforced concrete shear wall in multistoried buildings is sometimes limited because of the large amount of reinforcement localized at the end of the element. The steel-concrete composite shear walls are used as lateral load resisting system for high-rise buildings as an alternative to reinforced concrete shear wall.

Different types of composite walls have been studied by research scholars to enhance lateral stiffness of conventional reinforced concrete shear wall. Many of them performed nonlinear analysis of composite shear wall systems such as cantilever composite walls, where steel components are embedded in or attached to reinforced concrete walls, hybrid

Dr.D.K. Kulkarni, Professor, S.D.M. College of Engineering and Technology, Dharwad, Karnataka, India.E-mail:dkkulkarni@ rediffmail.com P.P. Phadnis, Research Scholar, Department of Technology, Shivaji University, Kolhapur, Maharashtra, India.E-mail:ppp_tech@unishivaji.ac.in DOI:10.9756/BIJMMI.8183 coupled walls, where steel beams are used to couple two or more reinforced concrete or composite walls in series and hybrid dual system, where reinforced concrete walls are placed parallel with steel beams [9, 12]. Shear walls with concrete filled steel tube columns and concealed steel trusses are used to improve ductility of structure [4]. Finite element packages such as ABAQUS, ATENA2D and BIOGRPH are used to model a complex geometry and finite element analysis is carried out in order to obtain analysis results of deformation, stress distribution, and the evolution of cracks [2, 3, and 13]

In this paper, one reinforced concrete shear wall (SW1) and three possible solutions of shear walls with steel encased profiles, called composite shear walls (SW2 to SW4) are proposed and analyzed. Shear walls are modeled by considering material non-linearity and pushover analysis is performed in SAP2000 in order to predict actual behavior of structure during earthquake. The base shear versus displacement curves are verified with available experimental results. Further, composite steel-concrete shear walls encased with different Indian standard steel sections are modeled. All shear walls are provided with almost equal steel area. The pushover curve obtained shows that, composite steel-concrete shear wall have increased stiffness and ductility than conventional reinforced concrete shear wall.

\section{THEORETICAL ASPECTS REgarding COMPOSITE STEEL CONCRETE SHEAR WALLS}

The European standard EN 1994-1-1, Eurocode 4: Design of composite steel and concrete structures: general rules and rules for buildings [8] describe the principles and requirements for resistance, serviceability and durability of composite steel concrete structures. The simplified design method for composite compression members, which is limited to doubly symmetrical and uniform cross section along the element length gives the plastic resistance to compression of a composite cross section fully encased steel section as:

$$
N_{p l, R d}=A_{s t} f_{y d}+0.85 A_{c} f_{c d}+A_{s r} f_{s r d}(1)
$$

where,

$\mathrm{A}_{\mathrm{st}}, \mathrm{A}_{\mathrm{c}}, \mathrm{A}_{\mathrm{sr}}=$ cross sectional areas of structural steel, concrete and reinforcement of the composite cross section respectively;

$f_{y d}=$ design value of yield strength of structural steel;

$\mathrm{f}_{\mathrm{cd}}=$ design value of compression strength of concrete;

$f_{\text {srd }}=$ design value of yield strength of reinforcement. 
The plastic moment resistance of a doubly symmetric composite cross-section may be evaluated as follows:

$$
M_{p l, R d}=f_{y}\left(Z_{p s t}-Z_{p s t n}\right)+0.5 f_{c d}\left(Z_{p c}-Z_{p c n}\right)+f_{s r d}\left(Z_{p s r}-Z_{p s r n}\right)(2)
$$

where,

$\mathrm{Z}_{\mathrm{pst}}, \mathrm{Z}_{\mathrm{pc}}, \mathrm{Z}_{\mathrm{psr}}=$ plastic section modulus for steel section, concrete and reinforcement of composite cross section respectively (for the calculation of $\mathrm{Z}_{\mathrm{pc}}$ the concrete is assumed to be uncracked;

$Z_{\mathrm{pstn}}, \mathrm{Z}_{\mathrm{pcn}}, \mathrm{Z}_{\mathrm{psrn}}=$ plastic section modulus of the corresponding components within the region of $2 h_{n}$ from the middle line of composite cross section for steel section, concrete and reinforcement of composite cross section respectively;

$\mathrm{h}_{\mathrm{n}}=$ depth of the neutral axis from the middle line of cross section.

\section{EFFECT OF CONCRETE CRACKING ON THE PUSHOVER ANALYSIS}

In the present study, effect of material non-linearity due to concrete cracking on pushover response of shear wall has been included. The flexural stiffness reduction in structures, due to concrete cracking amplifies the lateral deflection.

The main parameters affecting the stiffness of cracked section are modulus of elasticity and moment of inertia. The effective moment of inertia, $\mathrm{I}_{\mathrm{e}}$, concept to reflect the concrete cracking which is more than or equal to the moment of inertia of a cracked section and is lesser than or equal to the moment of inertia of gross section.

Ahmed et al. provided modification factors recommended in different country standards to determine effective moment of inertia of cracked section. Eurocode 8 recommends the effective flexural rigidity of reinforced concrete elements as 0.5 time gross moment of inertia for the consideration of cracking. [11]

\section{MODELING}

In the present work, a conventional reinforced concrete shear wall and composite steel-concrete shear wall modeled by using section designer utility available in SAP2000 for equivalent frame element.

It is well known that nonlinear stress-strain relationship of construction materials are a common cause of nonlinear structural behavior. Fig.1 represents stress-strain plot for Mander's model of confined concrete, Park's model for reinforcing steel and simple model for structural steel which are available in SAP2000 to include effect of nonlinear stressstrain behavior. [5]

Mander's confined concrete stress-strain curve calculates the compressive strength and ultimate strain values as a function of the transverse reinforcing steel.

Park's reinforcement steel stress-strain curve has three regions i.e. elastic, perfectly plastic and strain hardening and uses an empirical shape in strain hardening region.
Simple structural steel stress-strain curve has four regions i.e. elastic, perfectly plastic and strain hardening and softening region.

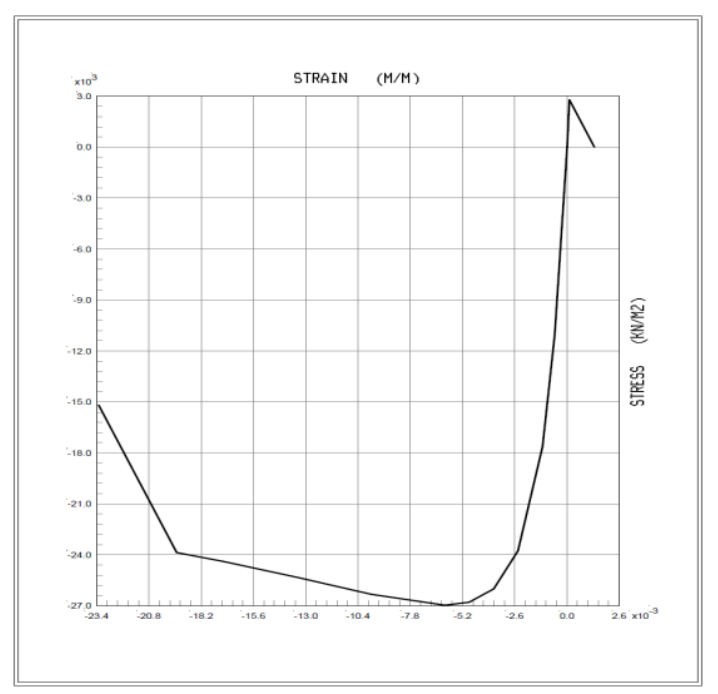

(a) Mander's Confined Concrete Stress-Strain Curve

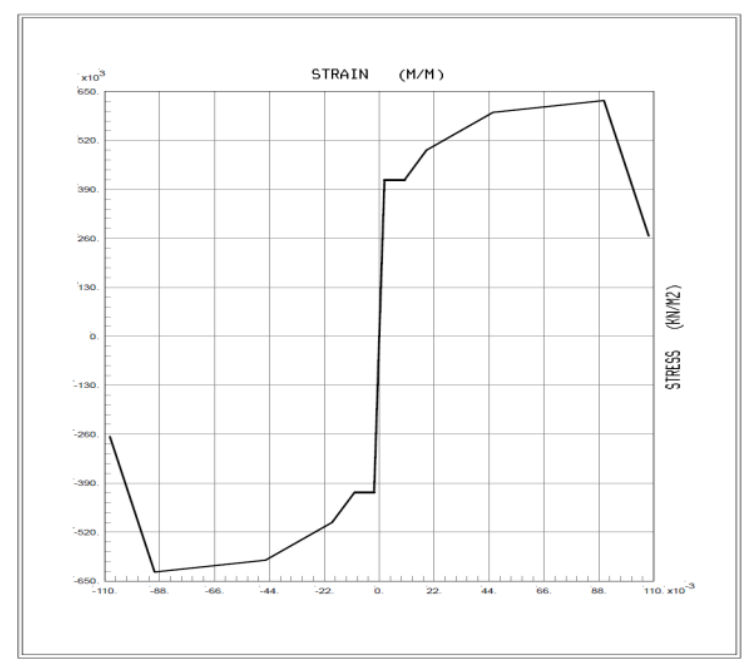

(b) Park's Reinforcement Steel Stress-Strain Curve

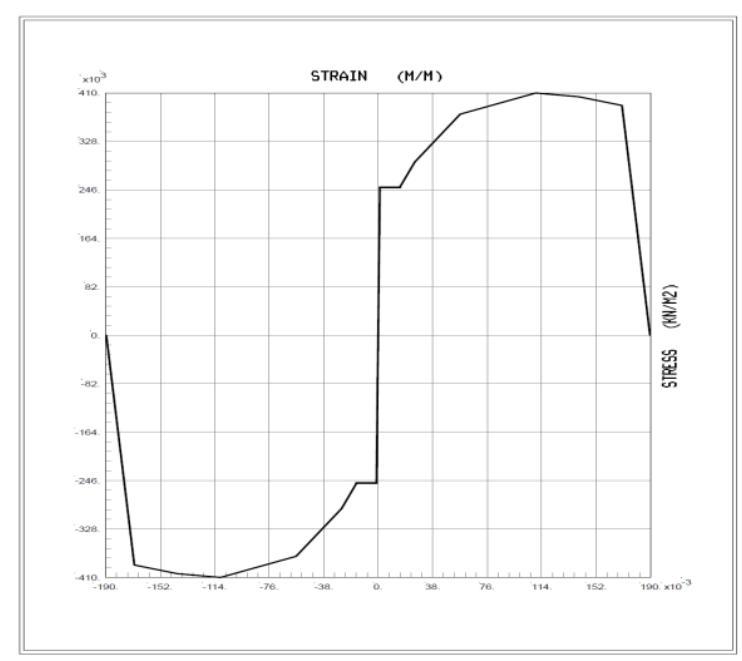

(c) Simple Structural Steel Stress-Strain Curve

Figure 1: Stress-Strain Curve for Materials (Units: kN, m, C) 
Four proposed specimens with aspect ratio 1:3 are provided with dimensions as $1000 \mathrm{~mm}$ length, $3000 \mathrm{~mm}$ height and $150 \mathrm{~mm}$ depth and materials M20 concrete, Fe415 rebar steel and Fe410 structural steel. Properties of materials are tabulated in table I and table II.

Table 1: Properties of Steel Materials

\begin{tabular}{|l|l|l|l|}
\hline Type of Material & $\begin{array}{l}\text { Yield strength } \\
\left(f_{y}\right)\left(\mathrm{N} / \mathrm{mm}^{2}\right)\end{array}$ & $\begin{array}{l}\text { Ultimate } \\
\text { tensile } \\
\text { strength } \\
\left(f_{u}\right) \\
\left(\mathrm{N} / \mathrm{mm}^{2}\right)\end{array}$ & $\begin{array}{l}\text { Young's } \\
\text { Modulus } \\
\left(E_{s}\right) \\
\left(\mathrm{N} / \mathrm{mm}^{2}\right)\end{array}$ \\
\hline $\begin{array}{l}\text { Steel Reinforcement } \\
\text { Fe415 }\end{array}$ & 415 & 485 & $2 \times 10^{5}$ \\
\hline $\begin{array}{l}\text { Structural Steel for } \\
\text { encased profile Fe410 }\end{array}$ & 250 & 410 & $2 \times 10^{5}$ \\
\hline
\end{tabular}

Table 2: Properties of concrete materials

\begin{tabular}{|l|l|l|}
\hline Type of Material & $\begin{array}{l}\text { Specified Compressive } \\
\text { Strength }(f \mathrm{fck}) \\
\left(\mathrm{N} / \mathrm{mm}^{2}\right)\end{array}$ & $\begin{array}{l}\text { Young's } \\
\text { Modulus } \\
(\mathrm{Ec}) \\
\left(\mathrm{N} / \mathrm{mm}^{2}\right)\end{array}$ \\
\hline $\begin{array}{l}\text { Concrete M20 for Composite } \\
\text { Shear wall }\end{array}$ & 20 & 22360 \\
\hline $\begin{array}{l}\text { Concrete M30 for Conventional } \\
\text { RC Shear wall }\end{array}$ & 30 & 27386 \\
\hline
\end{tabular}

The encased steel profiles are 2ISLB75, 2 Circular Pipes with outer diameter $60.3 \mathrm{~mm}$ and thickness $5.15 \mathrm{~mm}$ and 4ISA $45 \times 45 \times 5$. The steel sections are connected with concrete by headed shear stud connectors with $13 \mathrm{~mm}$ diameter and $75 \mathrm{~mm}$ in length. The shear studs for the composite steelconcrete shear walls are designed to ensure full interaction between the two materials. The reinforcement is provided by vertical bars $10 \mathrm{~mm}$ diameter at $100 \mathrm{~mm}$ centre to centre and confinement zone is provided with $8 \mathrm{~mm}$ diameter stirrups at $150 \mathrm{~mm}$ centre to centre. The reinforcement is placed on both sides of shear walls. In the analysis as boundary conditions, all the degrees of freedom for the bottom nodes of the specimen are restricted.

First specimen is a conventional RC shear wall with the extra amount of reinforcement concentrated at the extremities which is modeled in SAP2000 using section designer utility for graphically defines unusual sections.

This extra reinforcement provided in the extremities of conventional reinforced concrete wall is replaced by equal steel area of structural steel section in composite steelconcrete shear wall. Using this option of adding extra steel shapes the structural steel profiles are provided at the ends of composite steel-concrete shear wall.

The walls are modeled as shown in fig.2.

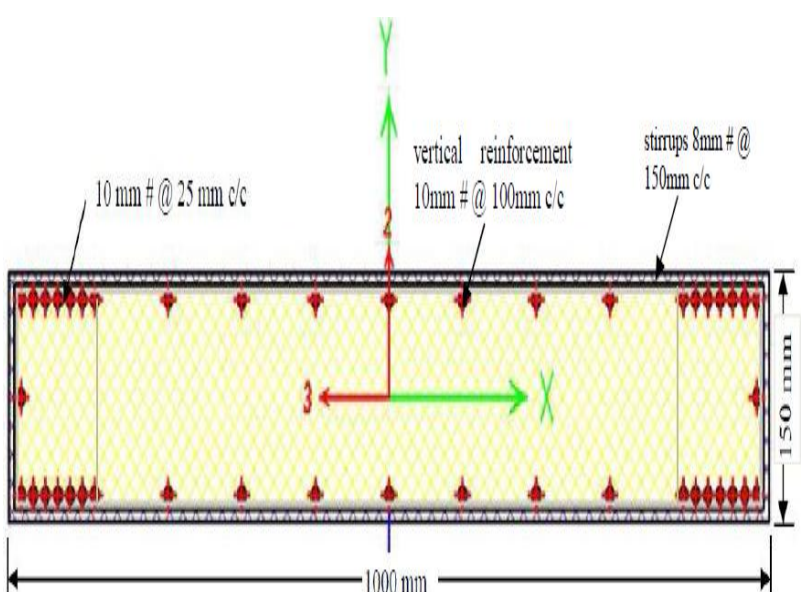

(a) SW 1: Conventional RC Shear wall

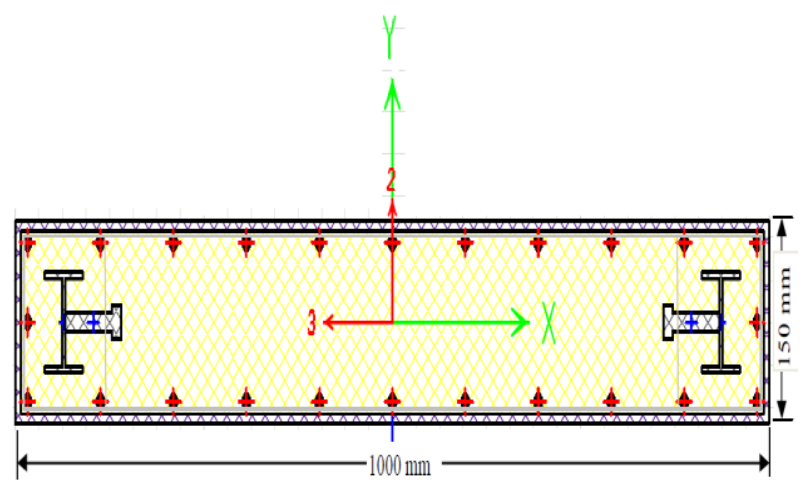

(b) SW 2: Composite Shear wall with 2 ISLB75

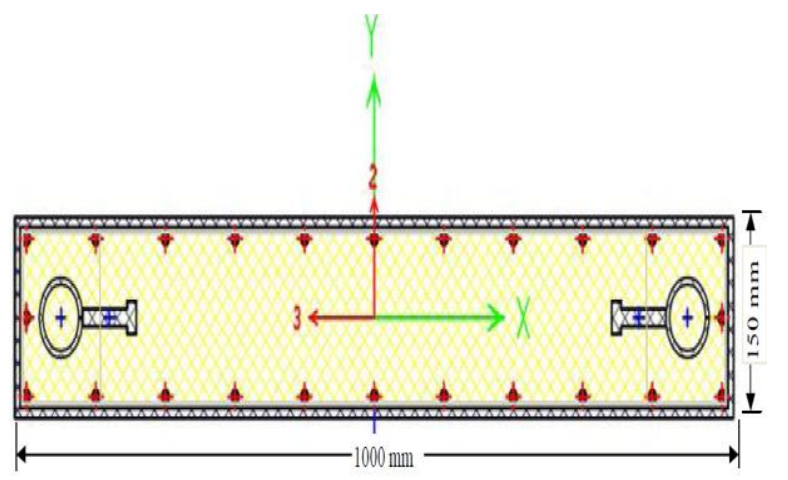

(c) SW 3: Composite Shear wall with 2 Hollow Circular pipe with outer diameter $60.3 \mathrm{~mm}$ and thickness $5.15 \mathrm{~mm}$

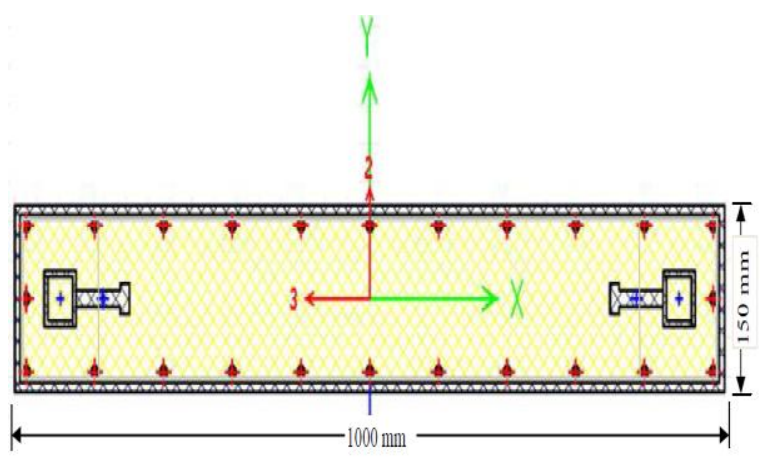

(d) SW 4: Composite Shear wall with 4 ISA $45 \times 45 \times 5$

Figure 2: Plan of Shear Wall 
In the implementation of pushover analysis, model must consider nonlinear behavior of element. According to Dan et al. to avoid brittle failure of element due to shear, first it is designed for bending and then by shear. [6] Hence, to introduce local non-linear effects, such as flexural hinge assumed to occur at the end of element. Default hinges are assigned according FEMA356 in SAP2000. [5, 10]

Fig. 3 shows the vertical sectionof the shear wall and location where the hinge is modeled.

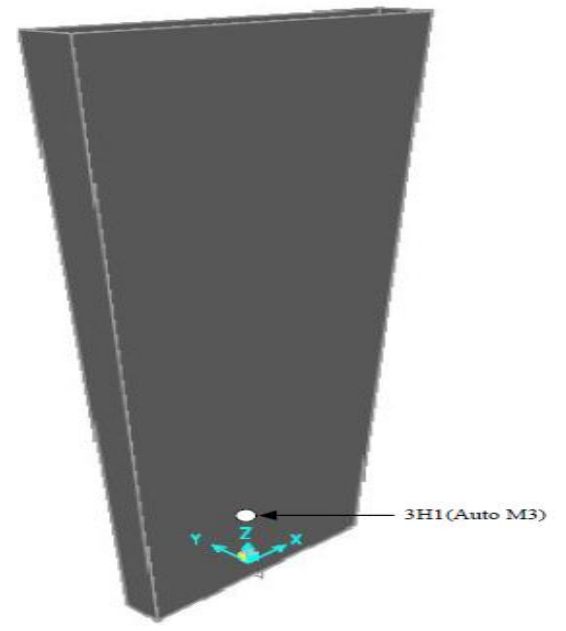

Figure 3: Vertical Section of Shear Wall with Assigned M3 Hinge

Table III provides moment rotation values for M3 hinge.

Table 3: Moment-Rotation Values for M3 Hinge

\begin{tabular}{|l|l|l|l|l|l|l|l|}
\hline \multicolumn{2}{|c|}{ SW1 } & \multicolumn{2}{c|}{ SW2 } & \multicolumn{2}{c|}{ SW3 } & \multicolumn{2}{c|}{ SW4 } \\
\hline-121.12 & -0.03 & -139.08 & -0.03 & -142.51 & -0.03 & -707.54 & -0.03 \\
\hline-121.12 & -0.02 & -139.08 & -0.02 & -142.51 & -0.02 & -778.29 & -0.02 \\
\hline-666.14 & -0.02 & -764.94 & -0.02 & -783.79 & -0.02 & -141.51 & -0.02 \\
\hline-605.59 & 0 & -695.40 & 0 & -712.53 & 0 & -141.51 & 0 \\
\hline 0 & 0 & 0 & 0 & 0 & 0 & 0 & 0 \\
\hline 605.59 & 0 & 695.40 & 0 & 712.53 & 0 & 141.51 & 0 \\
\hline 666.14 & 0.02 & 764.94 & 0.02 & 783.79 & 0.02 & 141.51 & 0.02 \\
\hline 121.12 & 0.02 & 139.08 & 0.02 & 142.51 & 0.02 & 778.29 & 0.02 \\
\hline 121.12 & 0.03 & 139.08 & 0.03 & 142.51 & 0.03 & 707.54 & 0.03 \\
\hline
\end{tabular}

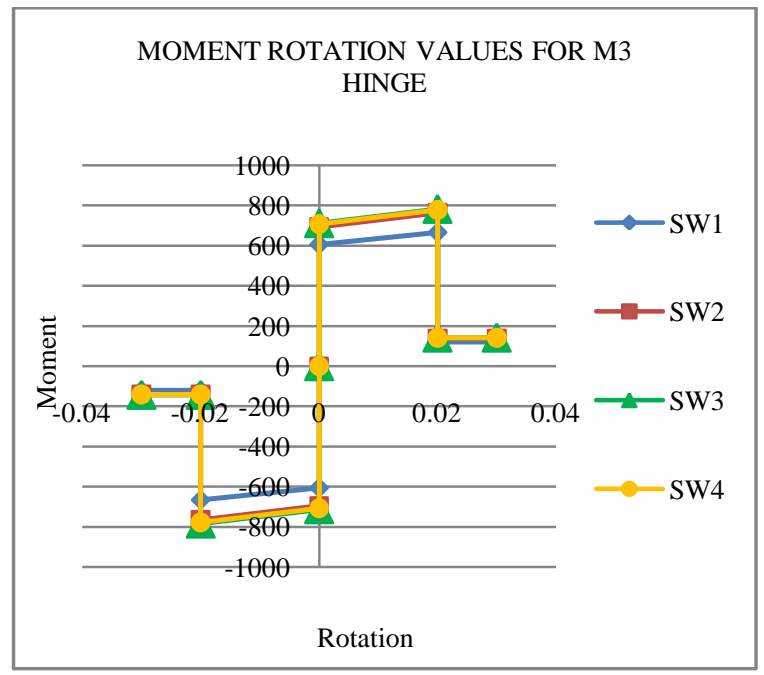

Figure 4: Moment-Rotation (M- $\theta$ ) Relation for Different Shear Wall Specimens
Flexural rigidity modification factor of 0.5 is assigned to the specimens to incorporate the effect of concrete cracking as per EC 8. [7]

The dead load and live load from tributary slab areas are applied as concentrated load on wall. (Here, $\mathrm{DL}+\mathrm{LL}=100 \mathrm{kN}$ )

\section{Pushover ANALYSIS OF COMPOSITE SHEAR WALL}

Pushover analysis is performed on composite shear wall to assess the capacity of structure by using SAP2000. Pushover analysis consists of application of gravity loads and a representative lateral load pattern. The shear walls are subjected to gravity analyses and simultaneous gravity loading. Gravity loads are in place during lateral loading. Lateral forces are applied monotonically in a step by step nonlinear static analysis. The applied lateral forces are proportional to the product of mass and acceleration. In pushover analysis, the behavior of the structure is characterized by a capacity curve that represents a relationship between base shear force and top displacement.

The nonlinear behavior in structure can arise from different causes such as geometric nonlinearities and material nonlinearities. The geometric nonlinearities are caused due to large deformations experienced by structures, which can cause geometric changes in a structure. Nonlinear stress-strain relationship of construction materials are a common cause of nonlinear structural behavior. Many factors can influence material's stress-strain properties, including elastic-plastic response during loading, environmental conditions and creep response of materials.

In this paper, the nonlinear behavior in steel concrete composite shear walls due to nonlinear properties of concrete and steel materials is included in the analysis. Further, displacement controlled pushover analysis is performed with loads applied automatically as uniform acceleration in the lateral direction in SAP2000. In this case, the lateral force automatically applied at each node is proportional to the mass tributary to that node. The resulting base shear and roof top displacements are monitored to plot pushover curve.

\section{RESULTS AND DISCUSSION}

The resulting pushover curves are as shown in fig. 5 .

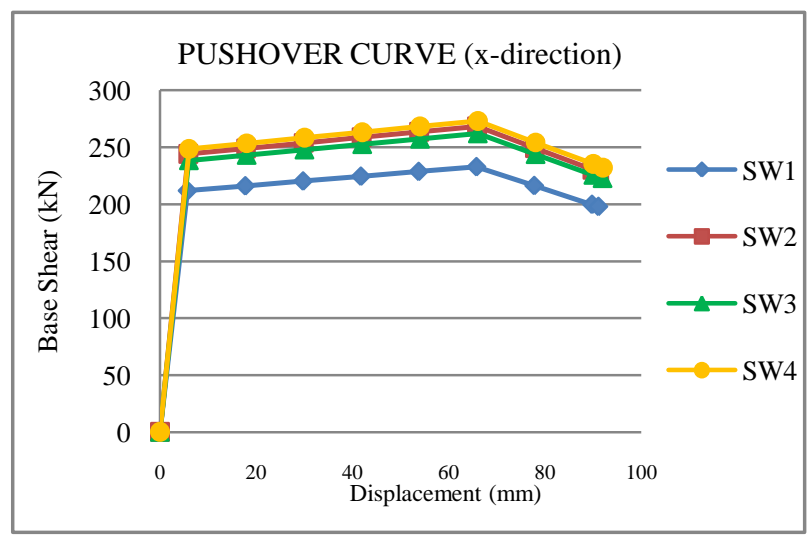

Figure 5: Force-Displacement Relationship for Default M3 Hinge 
Table 4: Force Displacemennt Relationship

\begin{tabular}{|c|c|c|c|c|c|c|c|c|}
\hline \multirow{2}{*}{ Specimen } & \multicolumn{2}{|c|}{$\begin{array}{l}\text { Element } \\
\text { Yielding }\end{array}$} & \multicolumn{2}{|c|}{ Ultimate Stage } & \multicolumn{2}{|c|}{ Failure Stage } & \multirow{2}{*}{$\begin{array}{l}\text { Moment of } \\
\text { Resistance by } \\
\text { SAP2000 } \\
\quad \boldsymbol{M}_{\boldsymbol{p l}, \boldsymbol{R} \boldsymbol{d}} \\
(\mathrm{kNm})\end{array}$} & \multirow{2}{*}{$\begin{array}{l}\text { Moment of Resistance by } \\
\text { calculations according to } \\
\text { Eurocode } 4\end{array}$} \\
\hline & $\begin{array}{l}P_{y} \\
(k N)\end{array}$ & $\begin{array}{l}\Delta_{y} \\
(\mathrm{~mm})\end{array}$ & $\begin{array}{l}P_{\max } \\
(k N)\end{array}$ & $\begin{array}{l}\Delta_{\max } \\
(m m)\end{array}$ & $\begin{array}{l}P_{85 \% \max } \\
(k N)\end{array}$ & $\begin{array}{l}\Delta 85 \% \max \\
(\mathrm{mm})\end{array}$ & & \\
\hline SW 1: Conventional RC Shear wall & 211.84 & 5.73 & 232.82 & 65.73 & 197.90 & 91.06 & 605.00 & 512.80 \\
\hline SW2: Composite Shear wall with 2 ISLB75 & 244.10 & 5.90 & 268.27 & 65.90 & 228.27 & 91.29 & 695.40 & 647.83 \\
\hline $\begin{array}{l}\text { SW3: Composite Shear wall with } 2 \text { Hollow } \\
\text { Circular pipe with outer diameter } 60.3 \mathrm{~mm} \\
\text { and thickness } 5.15 \mathrm{~mm}\end{array}$ & 238.28 & 6.01 & 261.87 & 66.01 & 222.59 & 91.92 & 712.53 & 657.12 \\
\hline $\begin{array}{l}\text { SW4: Composite Shear wall with } 4 \\
\text { ISA45 } \times 45 \times 5\end{array}$ & 248.38 & 6.03 & 272.97 & 66.03 & 232.02 & 92.02 & 707.53 & 654.00 \\
\hline
\end{tabular}

Table 5: Summary of Plastic Hinge Mechanism for Pushover Analysis at Different Damage Levels

\begin{tabular}{|c|c|c|c|c|c|c|c|c|c|c|}
\hline Hinge Damage states & & $A \cdot B$ & B-IO & IO-LS & LS-CP & $\mathrm{CP}-\mathrm{C}$ & C.D & $\mathrm{D}-\mathrm{E}$ & $>E$ & Total \\
\hline \multirow{3}{*}{ SW 1: Conventional RC Shear wall } & Yield & 1 & 1 & 0 & 0 & 0 & 0 & 0 & 0 & 2 \\
\hline & Ultimate & 1 & 2 & 2 & 0 & 0 & 2 & 0 & 0 & 7 \\
\hline & Failure & 1 & 2 & 2 & 0 & 0 & 7 & 0 & 0 & 12 \\
\hline \multirow{3}{*}{ SW2: Composite Shear wall with 2ISLB75 } & Yield & 1 & 1 & 0 & 0 & 0 & 0 & 0 & 0 & 2 \\
\hline & Ultimate & 1 & 2 & 2 & 1 & 0 & 1 & 0 & 0 & 7 \\
\hline & Failure & 1 & 2 & 2 & 1 & 0 & 6 & 0 & 0 & 12 \\
\hline \multirow{3}{*}{ SW3: Composite Shear wall with 2 Hollow Circular pipe with outer diameter $60.3 \mathrm{~mm}$ and thickness $5.1 \mathrm{sm}$} & Yield & 1 & 1 & 0 & 0 & 0 & 0 & 0 & 0 & 2 \\
\hline & Ultimate & 1 & 2 & 2 & 1 & 0 & 1 & 0 & 0 & 7 \\
\hline & Failuse & 1 & 2 & 2 & 1 & 0 & 6 & 0 & 0 & 12 \\
\hline \multirow{3}{*}{ SW 4 : Composite Shear wall with 4 ISA $45 \times 45 \times 5$} & Yield & 1 & 1 & 0 & 0 & 0 & 0 & 0 & 0 & 2 \\
\hline & Ultimate & 1 & 2 & 2 & 1 & 0 & 1 & 0 & 0 & 7 \\
\hline & Failure & 1 & 2 & 2 & 1 & 0 & 6 & 0 & 0 & 12 \\
\hline
\end{tabular}

Note: A-B: Details of hinges falling in Operational range, B-IO: Details of hinges falling in Operational and Immediate occupancy range, IO-LS: Details of hinges falling in immediate occupancy and Life Safety range, LS-CP: Details of hinges falling in Life Safety and Collapse Prevention range, CP-C: Details of hinges falling in Collapse Prevention and Ultimate Strength Range, C-D: Details of hinges falling in and Ultimate Strength and Residual Strength range, D-E: Details of hinges falling in Residual Strength and Failure range

Table IV represents force and displacement at element yielding, limit stage and failure stage. Failure stage is considered to be reached when horizontal load fall to $85 \%$ of maximum load attained and the corresponding displacements are tabulated in table IV.

SW1: Conventional reinforced concrete shear wall has very low base shear capacity $232.82 \mathrm{kN}$ and displacement of $91.06 \mathrm{~mm}$. While, SW4: Composite Shear wall with 4ISA $45 \times 45 \times 5$ has highest base shear capacity $272.97 \mathrm{kN}$ and displacement of $92.02 \mathrm{~mm}$ among all elements considered for analysis. It proves that, incorporation of encased steel sections at extremities in shear wall improves lateral resistance significantly and slightly increases ductility.

Slight increase in ductility of steel-concrete shear wall is observed, because Fe410 grade of steel used for structural steel in composite shear wall having yield strength of $250 \mathrm{~N} / \mathrm{mm}^{2}$ and all the elements are provided with equal area of steel.

Moment of resistance $\left(\mathrm{M}_{\mathrm{pl}, \mathrm{rd}}\right)$ obtained from SAP2000 and from calculations according to simplified method given in Eurocode 4 are shows good coherence. The difference between values is less than $15 \%$.

Table $\mathrm{V}$ summarizes the number of hinges at different damage levels. Hinge mechanism developed at yield level is same for all elements. However, there are differences in hinging pattern at the ultimate state. Comparison of hinging pattern shows ductile behavior of steel-concrete composite wall as compared to conventional reinforced concrete shear wall.

\section{CONCLUSION}

This paper describes the behavioral aspects for steelconcrete composite shear walls with encased structural steel sections. The following conclusions can be drawn

1. The observations show that, composite steel concrete shear wall subjected to earthquakes results in improving the performance of structural systems.

2. Non-linear analysis performed on four different types of shear walls results in increase in lateral stiffness in case of steel-concrete shear wall as compared to conventional reinforced concrete shear wall.

3. The displacement ductility has values that not differ very much for all elements, because Fe 410 grade of steel used for structural steel in composite shear wall having yield strength of $250 \mathrm{~N} / \mathrm{mm}^{2}$ and the amount of steel is almost same in all specimens. 


\section{REFERENCES}

[1] A. Ali, D. Kim and S. Cho, "Modeling of Nonlinear Cyclic Load Behavior of I shaped Composite Steel-Concrete Shear Walls of Nuclear Power Plants", Nuclear Engineering and Technology, Vol. 45, No. 1, 2013, Pp. 89-98.

[2] A. Fabian and D. Dan, "Further numerical analysis on Composite Steel-Concrete structure with shear walls with steel encased profiles", Proceedings of $11^{\text {th }}$ WSEAS International Conference in sustainability in Science and Engineering, 2009.

[3] A. Fabian, D. Daniel, V. Stoian, I. Demeter, T. Nagy-Gyorgy and C. Florut, "Comparative study concerning the seismic behaviour of composite steel-concrete structure steel encased profiles", Proceedings fib symposium PRAGUE, 2011.

[4] C. Wanlin, Z. Jianwei, D. Hongying and M. Wang, "Research on Seismic Performance of Shear Wall with Concrete filled Steel tube columns and concealed steel Trusses", Earthquake Engineering and Engineering Vibrations, Vol. 10, No. 4, Pp. 535-546, 2011.

[5] CSI, SAP 2000: Static and Dynamic Finite Element Analysis of Structures 14.0, Computers and Structures, Inc., Berkeley, California, 2009.

[6] D. Dan, A. Fabin, V. Stoian, "Theoretical and experimental study on composite steel-concrete shear wall with vertical steel encased profiles", Journal of Constructional Steel Research, Elsevier, Pp. 800-813, 2011.

[7] EC-8, 1994-2003, European Committee for Standardization, Design Provisions for Earthquake Resistance of Structures, Brussels.

[8] EN 1994-1-1, Eurocode 4: Design of composite steel and concrete structures, part 1-1, General Rules and Rules for Buildings.

[9] E. Spacone, A. M. Asce, S. E. Tawil and M. Asce, "Non-linear analysis of steel concrete composite structure- state of art", Journal of structural Engineering, Pp. 159-168, 2004.

[10] Federal Emergency Management Agency, Prestandard and Commentary for the Seismic Rehabilitation of Buildings, FEMA356, Building Seismic Safety Council, Washington, D.C., U.S.A., 2000.

[11] M. Ahmed, "Effect of Concrete Cracking on the Lateral Response of RCC Buildings", Asian Journal of Civil Engineering (Building and Housing) Vol. 9, No. 1, Pp. 25-34, 2008.

[12] M. Hassan, E.S. Tawil, M. Asce, "Inelastic Dynamic behavior of Hybrid coupled wall", Journal of Structural Engineering, ASCE, 2004.

[13] V. Stoian, D. Dan and A. Fabian, "Composite Shear Walls with Encased Profiles, New Solution for Buildings Placed in Seismic Area", Acta Technica Napocensis, Civil Engineering and Architecture, Vol. 54, 2011. 